\title{
THE EFFECT OF SALARY SATISFACTION, WORK SATISFACTION AND ORGANIZATIONAL COMMITMENT TO WORK INTENTION
}

\author{
Meithiana Indrasari ${ }^{1}$, Bambang Raditya Purnomo ${ }^{2}$,Eddy Yunus ${ }^{3}$, Eny Haryati ${ }^{4}$, Abdul Razzak Hashmi ${ }^{5}$, \\ ${ }^{1,2,3}$ Faculty of Economics and Business, Dr. Setomo University Surabaya, \\ ${ }^{4}$ Faculty of Administration Science, Dr Soetomo Univrsity Surabaya, \\ ${ }^{5}$ Al Baha University, Kingdom Of Saudi Arabia \\ E-mail: meithiana.indrasari@unitomo.ac.id
}

Abstract. High rate of turnover leads to adverse effect to an organization. Such problem is likely generating instability and uncertainty towards employment condition and human resources cost rise in forms of training invested to them, recruitment and newly built training programs. High turnover, in addition, also results in organizational ineffectiveness because it loses experienced employees as well as spends much times in training new, inexperienced employees.

This study aims to analyze the effect of salary satisfaction, work satisfaction and organizational commitment on withdrawal intention and to analyze the most affective variable on withdrawal intention. There are 115 respondents for the samples and data analysis during the research is held by using SEM and AMOS 5 program.

According to the analysis, it is concluded as the followings: work satisfaction has a positive effect on organizational commitment $(C R=6.052)$; salary satisfaction has a negative effect on turnover $(C R=-$ 4.306); job satisfaction has a negative effect on turnover $(C R=-4.846)$; and organizational commitment has a negative effect on turnover $(C R=-2.822)$.

Keywords: Salary Satisfaction, Job Satisfaction, Organizational Commitment, Turnover Intention.

\section{INTRODUCTION}

The high turnover rate which will cause a negative impact to the organization, it is like creating instability and uncertainty against labor conditions and the rising cost of resources human namely in the form of training costs that have been invested in employees until the costs of recruitment and retraining. High turnover also results in ineffective organizations because companies lose experienced employees and need to retrain new employees.

Based on the results of the Deloitte Millennial Survey (2016) stated that, for the next five years the number of employees who wished to leave the organization amounted to $66 \%$ with $27 \%$ of employees wanting to remain in the organization, while the remaining $7 \%$ had the desire to leave the organization at the time over the next five years. This survey involved 29 countries with themethod interview. Based on the survey results, employees in Indonesia have a $62 \%$ desire to leave the company where they work for the next five years.

According to Harnoto (2002: 2): Turnover intentions are characterized by various things concerning employee behavior, among others: increased absenteeism, lazy work, increased courage to violate work rules, courage to oppose or protest to superiors, and seriousness to resolve all employee responsibilities are very different from usual. These indications can be used as a reference to predict 
turnover intentions employeein a company (Harnoto 2002, 2).

High turnover intention can grab the attention of companies because it can disturbing company activities, and catapulting costs such as recruitment, interviews, tests, holiday allowances. The higher the turnover intention of the company, the more often the company experiences employee turnover or turnover, and the costs incurred by the company are far greater. turnover intention Lowcan minimize employee turnover and costs incurred (Dubas and Nijhawan, 2007).

Handoko (1998), states that one of the administrative purposes of compensation in this case is payroll to retain existing employees, if compensation is not competitive and does not meet the principle of justice, then there will be implications for the number of good employees going out.

Satisfaction and dissatisfaction with the salary received is a function of the discrepancy between what someone feels will be accepted and how much someone receives. Salary satisfaction can predictabsenteeism and turnover employee. Many studies conclude that the relationship between salary satisfaction and exit intention is negative (Motowildo, 1983 on Lum et al., 1998; Yuyetta, 2002).

According to Mobley (1977) on Judge (1993), the desire to end a task or leave an organization is negatively related to job satisfaction. Job satisfaction that is felt can affect one's thinking to get out. Evaluation of various employment alternatives will ultimately lead to turnover because individuals who opt out of the organization will expect more satisfying results elsewhere.

Job satisfaction is also negatively associated with employee (turnover intention) but other factors such as labor market conditions, alternative employment opportunities, and length of employment are important obstacles to abandoning existing work (Robbins, 2001; Tett and Meyer, 1995; Johnson et al., 1987). Individuals who feel satisfied with their work tend to stay in the organization. While individuals who feel less satisfied with their work will choose to leave and the organization.

Research conducted by Meyer et al. (1993) support that increased commitment is associated withproductivity and turnover lower. Organizational commitment contributes in predicting important organizational variables related to outcomes (for example: intention to leave). The outcome variables tested in this study relate to individual desires to leave the organization and the sample used is nurses. Meyer also concluded that organizational commitment is significantly related to the individual's desire to leave office and activities in the organization. Workers with strong affective commitment will remain in the organization because they feel that they should work that way (Johson et al., 1987; Tett and Meyer, 1995; Lum et al., 1998).

According to the results of research by Shore and Martin (1989) and Muller and Price (1990), quoted from Lum et al. (1998), concluded that job satisfaction and commitment are related to turnover, although organizational commitment has a stronger relationship to exit intention, meaning that job satisfaction is a variable that precedes organizational commitment.

PT Nusantara Indah is a business entity providing labor services and chartering work that was established in the city of Surabaya since 2007. Aside from legality, PT Nusantara Indah is one of the pioneers of labor supply service companies that respected regulations in terms of employment and wages since the company was founded.

This study tries to examine further previous research that examines salary satisfaction, job satisfaction, organizational commitment to the desire to move carried out by Lum. L. Kervin, J. Clark, K. Reid. F and Sirola. W (1998) with the title "Explaining Intensive Nursing Turnover: Job Satisfaction, Salary Satisfaction or Organizational Commitment". What is done at hospitals in Florida with 466 employees with questionnaire-shaped data collection methods with a Likert scale. The data analysis technique used is Multiple Linear Regression.

This study aims to answer the question of whether Salary and SatisfactionJob Satisfaction affect Organizational Commitment and impact on the intention to move work at PT. Nusantara Indah. 
DIDASKALIA, VOLUME 1 NUMBER 1 OCTOBER 2018

\section{LITERATURE REVIEW}

\section{Turn Over Intention}

Intention to Move Work (Turnover Intention) is the process by which workers leave the organization and there should replace (Mathis \& Jackson, 2001). Intention of Moving Work is a movement that crosses the membership limit of an organization, the shift of work in this case is the displacement of voluntary work that can be avoided and which cannot be avoided (Simamoa, 1996). Intention of Moving Work reflects the desire of individuals to leave the organization and look for other alternative jobs (Suwandi \& Indriantoro, 1999)

model Turnover intention developed by March and Simon (1958), Mobley (1977), Price (1977) on Lum et al. (1998) all three predict the same thing about someone's desire to leave the organization, that is an evaluation of one's current position regarding dissatisfaction can trigger a person's desire to go out and find another job.

The causes of changing jobs include workers having salary satisfaction, job satisfaction and low organizational commitment to their current work and are motivated to look for other jobs.

\section{Organizational Commitment}

Commitment according to William and Hazer (1986) quoted from Lum et al., (1998) defined the frequency level of identification and individual attachment to the organization entered, where the characteristics of organizational commitment include one's loyalty to the organization, willingness to use the business above the name of the organization, the compatibility between one's goals and the goals of the organization.

Meyer and Allen, (1991) on Hackett et al., (1994) define organizational commitment as the degree to which workers identify themselves with the organization and its involvement in the organization.

Organizational commitment is the relationship of the broad relative strength between individuals and organizations, whose characteristics (Mowday et al., 1987) include;
1. The existence of strong beliefs and acceptance of the goals of organizational values,

2. willingness to try as much as possible for the organization, and the

3. existence of a certain desire to know participation in the organization.

\section{Salary Satisfaction Salary}

satisfaction can mean that a person will be satisfied with his salary when the perception of salary and what they get is as expected. Some studies identifying aspects of satisfaction found to be related to individual desires to leave the organization include satisfaction with wages and promotion of Lum et al. (1998); Tett \& Meyer (1993). Hellriegel \& White, 1973; Koch \& Steers, 1978; Kraut, 1975; Mobley et. al., 1978) on Suwandi and Indriantoro (1999)

Individuals feel a sense of justice (equity) towards the salary received in connection with work that done (Lum et al., 1998). Handoko, (1998) states that companies must pay attention to the principle of fairness in determining the policy of paying wages and salaries.

Salary satisfaction is a multidimensional satisfaction construct and consists of four sub dimensions namely salary level, salary management structure, salary and allowance increase (Heneman \& Schwab, 1988)

\section{Job Satisfaction}

Job satisfaction is an individual orientation that influences the role in work and the characteristics of the work. Handoko (1998), defines that job satisfaction is a pleasant or unpleasant emotional state with which employees. The entry of labor is very much related to job dissatisfaction (Mathis \& Jackson, 2001).

Job satisfaction is also negatively associated with employee(turnoverturnover intention) but other factors such as labor market conditions, alternative employment opportunities, and length of employment are important obstacles to leaving existing jobs (Robbins, 2001). A`4 
Employees with high job satisfaction will feel happy and happy in doing their work and not trying to evaluate other work alternatives. Conversely, employees who feel dissatisfied in their work tend to have thoughts of going out, evaluating other work alternatives and wanting to leave because they hope to find more satisfying work (Lum et al, 1998)

\section{Conceptual Framework Research}

Turnover Intention affects organizational effectiveness, turnover the high results in an increase in investment costs in human resources (HR), and can cause instability and uncertainty regarding the condition of the workforce so that this can have implications for the company's performance. This high turnover rate tends to be identified due to several factors including salary satisfaction and low job satisfaction and lack of organizational commitment from employees.

Organizational commitment greatly influences employees to be loyal to the company by expressing their concern for the company so that it can be concluded that organizational commitment influences outgoing intentions.

\section{FIGURE 1. FRAMEWORK FOR THE RESEARCH}

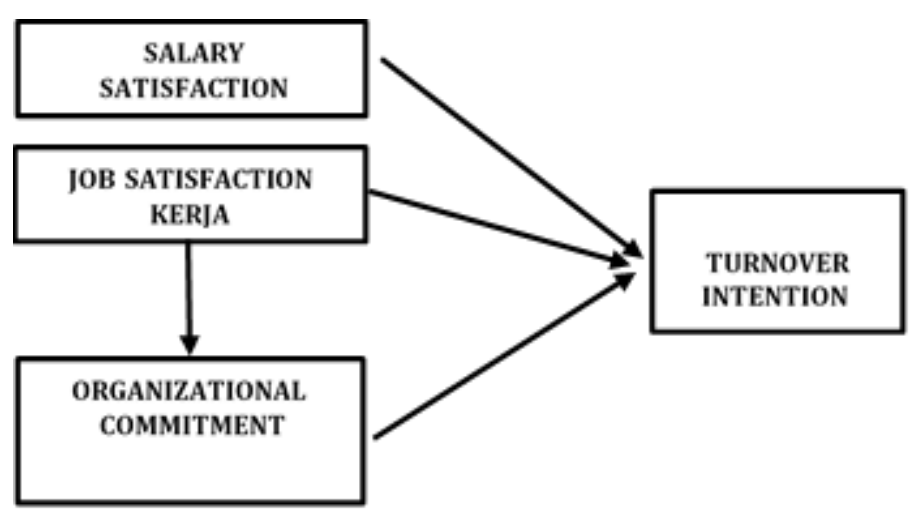

Source $\quad$ : Lum et al., 1998; Lance \& Vanderberg, 1992; Lee et al., 1992

\section{Hypothesis}

Based on the development of the above framework model, the hypotheses in this study are:

H1 : Salary Satisfaction negatively affects Turnover intention.
H2 : Job Satisfaction has a positive effect on Organizational Commitment

H3 : Job satisfaction has a negative effect on Turnover Intention.

H4 : Organizational Commitment negatively affects Turnover Intention

\section{RESEARCH METHODS}

\section{Research Subjects}

In this study the population used was employees of PT Nusantara Indah in Surabaya which aims to determine the level of salary satisfaction, job satisfaction and organizational commitment to the turnover intention of the company. The population in this study was 203 people.

The sample in this study is permanent employees who work more than two years with consideration of having experienced a relatively stable adjustment to organizational values. According to Hair et al. (1995), determine the formula for determining the number of samples taken for a study by multiplying the number of indicators 20 so that based on the Hair formula (1995), the number of sample sizes that are appropriate for SEM is as many as 100-200 respondents. The number of respondents in this study was 203 people. so, this has met the minimum requirements as suggested by Hair et. al., (1995).

\section{Data Collection}

This study are primary data in the form of questionnaires. The research questionnaire was designed based on theoretical studies and empirical research formulated in the form of open and closed questions. The respondents' identity data were obtained through open questions, while perception data were obtained through closed questions. The instrument used in this study uses a list of standard questions that have previously been tested for suitability, so that a list of standard questions is modified on items that are deemed necessary 
according to the level of understanding of the respondents taken as samples.

\section{Data Analysis Techniques}

researchers used the Structural Equation Modeling (SEM) program which was operated through the AMOS program. As a model of structural equation AMOS has often been used in management research, Bacon (1997). The AMOS casuality model describes measurement problems and structures and is then used to analyze and test hypotheses. AMOS is suitable for a variety of analyzes because of its ability to: (1) Estimate unknown coefficients of a set of structured linear equations, (2) Accommodate models which include latent variables, (3) Accommodate both dependent and independent error measurements (4) Accommodate reciprocal, simultaneous and interdependent warnings. This is as explained by Arbuckle (1997) and Bacon (1997) in Ferdinand (1999).

\section{Variables}

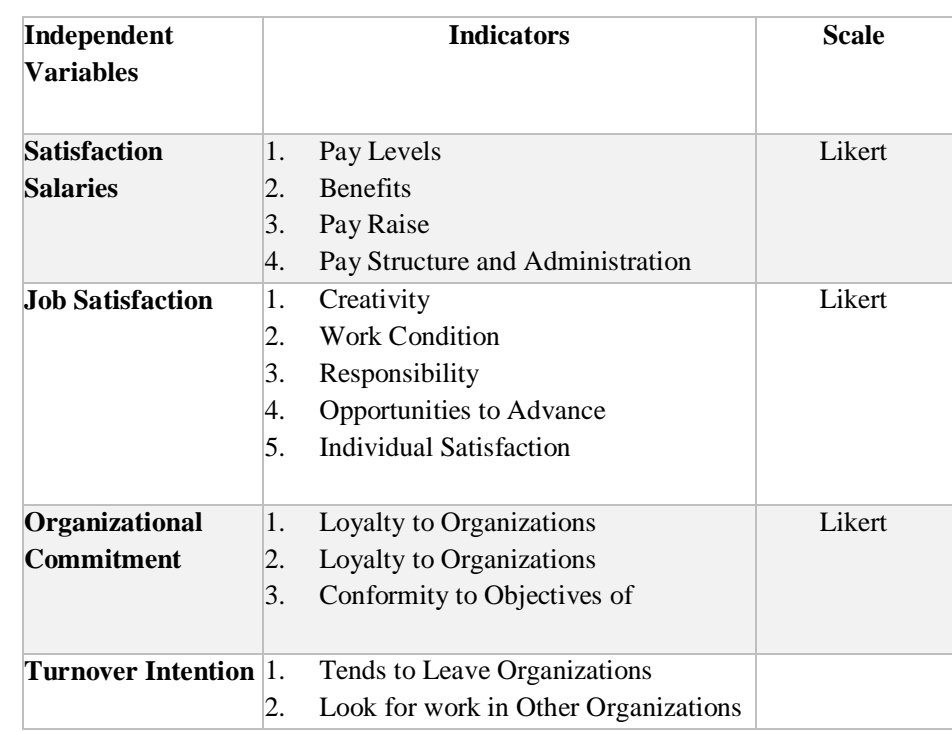

Source: Meyer \& Allen, 1991, William and Hazer, 1986, Lum et al., 1998; Lee et al., 1987 \& 1992

Table 1. Definition of Operational Variables

\section{RESEARCH FINDINGS AND DISCUSSION}

\section{Analysis of Structural Equation Modeling}

In this analysis tested causality relationships between variables included in the research model. Testing of Structural Equation Modeling (SEM) was carried out with two types of testing, namely test suitability of the model and causality test. The results of data processing for the analysis of full SEM models are shown in Figure 2, Table 2, and Table 3

\section{Figure 2.Results Structural EquationModel}

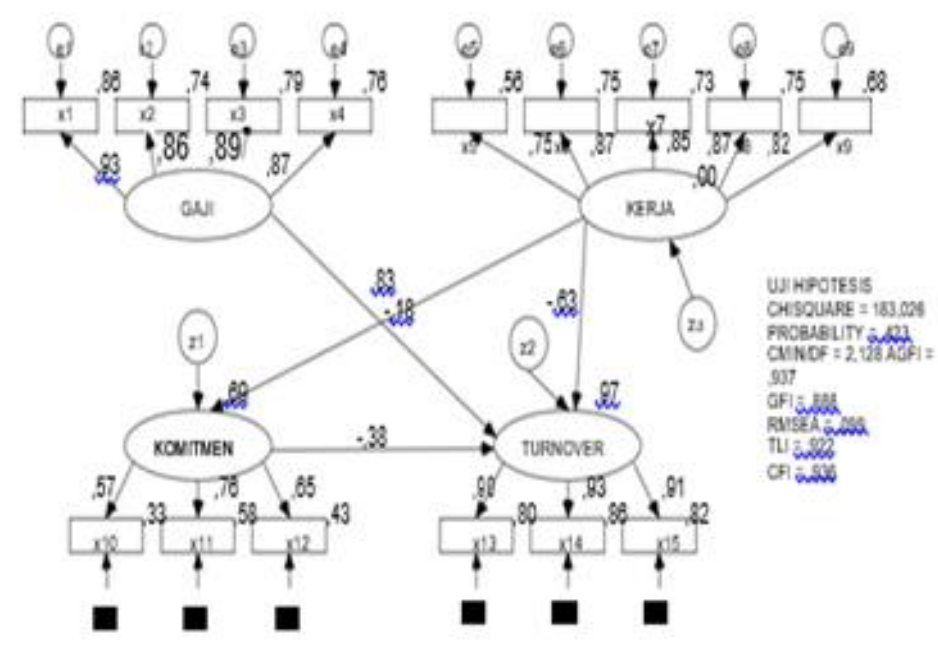

\section{Test of Suitability Model - Goodness of fit test}

This test was conducted to determine how well the Goodness of Fit level of the research model . This research must meet several criteria required in SEM. The results of data processing are expected to meet predetermined statistical limits.

Table 2. Goodness of Fit Indices for Full Model

\begin{tabular}{|c|c|c|c|}
\hline \multirow{2}{*}{$\begin{array}{c}\text { Goodness of } \\
\text { fit index }\end{array}$} & \multirow{2}{*}{ Cut off value } & Results of & Evaluation \\
\hline & & Analysis & Model \\
\hline Chi Square & $\begin{array}{l}\text { Small } \\
\text { expected }\end{array}$ & 183,026 & Marginal \\
\hline $\begin{array}{l}\text { Significancy } \\
\text { Probability }\end{array}$ & $>0,05$ & 0,425 & Good \\
\hline RMSEA & $<0,08$ & 0,099 & Marginal \\
\hline GFI & $>0,90$ & 0,888 & Marginal \\
\hline AGFI & $>0.90$ & 0.937 & Good \\
\hline CMIN / DF & $<1.96$ & 2.128 & Marginal \\
\hline TLI & $>0.95$ & 0.922 & Marginal \\
\hline CFI & $>0.95$ & 0.936 & Marginal \\
\hline
\end{tabular}

From the suitability test of this model, there are 2 indicators that have subpar values, namely GFI, CMIN / DF , TLI, CFI and and Chi Square this can occur because of the many variables and indicators studied, so that it has a level of complexity in the calculations in the SEM analysis tool, even though the value is still considered marginal and fit for the overall model (Hair, 1995) 
Table 3. Standardized Regression Weights

\begin{tabular}{|c|c|c|c|c|c|c|}
\hline & & & Estimate & & $\overline{C R}$ & $\bar{P}$ \\
\hline Commitment & $<-$ & Labor & 0,829 & 0.076 & 6.066 & 0.000 \\
\hline Turnover & $<-$ & Salary & -0.176 & 0.059 & -4.308 & 0.000 \\
\hline Turnover & $<-$ & Labor & -0.628 & 0.199 & -4.875 & 0.000 \\
\hline Turnover & $<-$ & Commitments & $-0,381$ & \begin{tabular}{|l|}
0.373 \\
\end{tabular} & \begin{tabular}{l|}
-2.852 \\
\end{tabular} & 0.004 \\
\hline $\mathrm{X} 1$ & $<-$ & Salary & 0.930 & & & \\
\hline $\mathrm{X} 2$ & $<-$ & Salary & 0.857 & 0.059 & 13.944 & 0,000 \\
\hline $\mathrm{X} 3$ & $<-$ & Salary & 0.890 & 0.063 & \begin{tabular}{l|}
15,307 \\
\end{tabular} & 0,000 \\
\hline $\mathrm{X} 4$ & $<-$ & Salary & 0.869 & 0.067 & \begin{tabular}{l|}
14,421 \\
\end{tabular} & 0,000 \\
\hline $\mathrm{X} 5$ & $<-$ & Work & 0.751 & & & \\
\hline X6 & $<-$ & Work & 0.868 & \begin{tabular}{l|l|}
0.109 \\
\end{tabular} & 9.837 & 0.000 \\
\hline $\mathrm{X} 7$ & $<-$ & Working & 0.852 & 0.111 & 9.634 & 0.000 \\
\hline $\mathrm{X} 8$ & $<-$ & Working & 0.868 & 0.121 & 9.840 & 0.000 \\
\hline X9 & $<-$ & Working & 0.825 & 0.115 & 9.272 & 0.000 \\
\hline $\mathrm{X} 12$ & $<-$ & Commitments & 0.654 & & & \\
\hline $\mathrm{X} 11$ & $<-$ & Commitments & 0.764 & 0.181 & 6.700 & 0.000 \\
\hline $\mathrm{X} 10$ & $<-$ & Commitment & 0.571 & 0.171 & 5.289 & 0.000 \\
\hline $\mathrm{X} 15$ & $<-$ & Turnover & 0.908 & & & \\
\hline $\mathrm{X} 14$ & $<-$ & Turnover & 0.928 & 0.061 & 16.788 & 0.000 \\
\hline $\mathrm{X} 13$ & $<-$ & Turnover & 0.896 & 0.059 & 15.254 & 0.000 \\
\hline
\end{tabular}

From Figure 2 and Table 3 above it can be concluded that the level of significance to test the hypothesis of difference is $\chi^{2}$ - Chi Square is 151,031 with Probability 0,050, indicating that the null hypothesis which states that there is no difference between the sample covariance matrix and the estimated population covariance matrix cannot be rejected, meaning the null hypothesis is accepted.

From Table 3 it can be concluded that the $\mathrm{CR}$ value $\geq 1.96$ indicates receipt of all hypothesis models in this study (H1-H4) or in other words all hypotheses regarding causality relationships as presented in this research model are acceptable.

\section{Hypothesis Testing The}

results of testing the Structural Equation Model found in Table 4.15 below are then examined further to accept or reject the hypothesis contained in this study.
Table 4. Testing of Hypotheses

\begin{tabular}{|l|l|l|r|r|r|l|}
\hline & & & Estimate & SE & CR & P \\
\hline Commitment & $<-$ & Work & 0.459 & 0.076 & 6.066 & 0,000 \\
\hline Turnover & $<-$ & Salary & -0.253 & 0.059 & -4.308 & 0,000 \\
\hline Turnover & $<-$ & Work & -0.970 & 0.199 & -4.875 & 0,000 \\
\hline Turnover & $<-$ & Commitment & -1.063 & 0.373 & -2.8852 & 0.004 \\
\hline
\end{tabular}

\section{H1: There is a negative influence on Salary Satisfaction on Turnover Intention.}

From the test results, the estimated parameter obtained between salary satisfaction and turnover results in a CR value of -4.308 , where this value satisfies the $C R$ requirement $\geq 2.0$ at the $5 \%$ significance level and value $\mathrm{p}=0,000$ fulfills the requirements $<0.05$. Thus it can be concluded that the second hypothesis is proven, namely the dimensions of salary satisfaction have an overall negative effect on turnover. The negative influence of job satisfaction on turnover indicates that employees who are satisfied with the salary they receive result in a lower desire for employees to do turnover. In addition, salary satisfaction is indicated by salary levels (pay level, compensation (benefits, increase in pay (pay raise) and payroll structure and administration (Pay structure and administration) that have been high in the eyes of employees resulting in low employee desires to leave the organization he works now and the possibility of individuals looking for work in other organizations

\section{H2: $\quad$ There is a positive influence on job satisfaction on Organizational Commitment}

The test results obtained the results of estimation parameters obtained between job satisfaction and organizational commitment results in a $\mathrm{CR}$ value $=$ 6.066 where this value meets the requirements $\mathrm{CR} \geq$ 1.96 at a significance level of $5 \%$ and the value of $p$ $=0.000$ fulfills the requirements $<0.05$. Thus it can be concluded that the first hypothesis is proven, namely the dimensions of job satisfaction have an overall positive effect on organizational commitment. organizational signifies an employee who is satisfied with creativity \& independence, working conditions, responsibilities, opportunities for advancement, individual satisfaction, creativity and achievement in accordance with the wishes of 
employees will result in increasing one's loyalty to the organization, willingness to use the business in the name of the organization (loyalty towards the organization) and the suitability between one's goals and organizational goals.

\section{H3: $\quad$ There is a negative influence on Job Satisfaction on Turnover Intention.}

From the test results, the estimated parameter obtained between work satisfaction and turnover results in a CR value of $-4,875$, where this value meets the $\mathrm{CR}$ requirement $\geq 2.0$ at the $5 \%$ significance level and $\mathrm{p}$ value $=0,000$ meets the requirements $<0.05$. Thus it can be concluded that the third hypothesis is proven, namely the dimensions of job satisfaction have an overall negative effect on turnover. The negative influence of job satisfaction which consists of creativity \& independence, working conditions, responsibilities, opportunities for advancement, individual satisfaction, creativity and achievement in accordance with the wishes of employees will result in low employee desire to leave the organization where he works now and the possibility of individuals find work with other organizations.

\section{H4: $\quad$ There is a negative influence of Organizational Commitment to TurnoverInetntion.}

From the test results obtained the results of estimation parameters obtained between organizational commitment and turnover produce a value of $\mathrm{CR}=-2,852$, where this value meets the $\mathrm{CR}$ requirements $\geq 2.0$ at a significance level of $5 \%$ and $\mathrm{p}$ value 0.004 meet the requirements $<0.05$. Thus it can be concluded that the second hypothesis is proven, namely the dimensions of organizational commitment have an overall negative effect on turnover. The negative turnover of organizational commitment indicates that employees who have someone's loyalty to the organization, willingness to use the business on behalf of the organization (loyalty to the organization) and the suitability of one's goals with organizational goals cause employees to have a low desire to leave the organization work now and the possibility that individuals will find work in other organizations.

\section{Conclusion}

This study provides significant support for the concept that states that salary satisfaction, job satisfaction and organizational commitment have a negative influence on turnover intention as an effort to reduce the turnover integral.

In an effort to reduce the turnover rate, PT Nusantara Indah must increase the level of salaries given to employees, provide adequate financial assistance to help the economy of employees, to improve relations between employees and between employees and superiors, to provide opportunities for employees to improve their quality through formal education, to strengthen loyalty to the company by meeting the needs and intentions of employees, and to increase employee awareness that they have an important role in supporting the development of the company.

This study also contributes specifically to the themes of turnover intention which have been previously examined by many scientists with variable factors or variables as a series of efforts to reduce turnover by increasing salary satisfaction, job satisfaction and organizational commitment. Thus the formulation of the problem in this study has been answered.

\section{REFERENCES}

Begley, T., \& Czajka, J. 1993. “ Panel Analysis of The Moderating Effects Of Commitment On Job satisfaction, Intent To Quit And Health Following Organizational Change". Journal of Applied Psyshology, vol 78, pp 552 556.

Charlie, G.T. 1997. "Voluntary Turnover and Job Performance : Carvenlinnearity and The Moderating Influency of Salary Growth and Promoting “Vol 82, No. 1.

Deloitte Millennial Survey. 2016. Winning Over

The Next Generation of Leaders. www.delloite.com. (Accessed July 4, 2017).

Donald R. Cooper and C. William Emory. 1999. Metode Penelitian Bisnis. Erlangga, Jakarta. 
Dubas, \& Nijhawan. 2007. A Humans Capitally Theory Perspectives of Sales Force Training, Productivity, Compensation, and Turnover. Allied Academies International Conference Academy of Marketing Studies Proceedings. 12 (2), pp: 21-25.

Ferdinand, A.T. 2000. Structural Equation Modeling Dalam Penelitian Manajemen. Badan Penerbit Universitas Diponegoro Semarang.

Hackett, R.D., Bycio ,P., \& Hausdorf, P.A. 1994. Further Assesment of Meyer and Allens (1991) Three-Component Model of Organizational Commiment. Journal of Applied Phsychology. 79 (1):15-23

Hair, J.F. Jr., et. al. 1995. Multivariate Data Analysis with Reading, 4rd Edition, Prentice-Hall International Inc., New Jersey.

Handoko, Hani. 1998. Manajemen Personalia dan Sumber Daya Manusia. BPFE. Yogyakarta.

Harnoto. 2002. Manajemen Sumber Daya Manusia. Jakarta: Prehallindo.

Hasibuan, MSP. 1996. Manajemen Sumber Daya Manusia. Bumi Aksara. Jakarta

Johson, M.W., Vandaranjan, P.R., Futrell, C.M., Sager, J. 1987. The Relationship Between Organizational Commitment, Job satisfaction, and Turnover Among New sales People. Journal of Personal Selling \& Sales Management, Vol 7: 29-38

Judge, T.A., \& Welbourne, T.M. 1994. A Confirmatory Investigation of Dimensionality of Pay Satisfaction Questionnaire. Journal of Applied Phsychology. 79(1); 461-466.

Kreitner, Robert \& Angelo Konicky. 2003. Perilaku Organisasi. PT. Salemba Empat Jakarta

Lee, T.W., Ashford S.J., Walsh, J.P. \& Mowday R.T. 1992. Commitment Propensity, Organizational Commitment and Voluntary Turnover: A longitudional Study of Organizational Entry Process. Journal of Management, 18 (1):15-32

Lum, Lille, John Kervin, Kathleen Clark, Frank Reid \& Wwayneendy Sola. 1998. Explaining
Nursing Turnover Intent : Job Satisfaction, Pay Satisfaction, or Organizational Commitment. Journal of Organizational Behavior. Vol. 19, 305-320

Mathis, Robert.L, \& John Jackson. 2001. Manajemen Sumber Daya Manusia. PT. Salemba Empat. Jakarta

Meyer, JP, \& Allen N.J. 1991. A Three Component Conceptualization of organizational Commitment, Human Resource Management Review.

Mowday R.T., et al. 1987. Voluntary Leaving Organization: An Empirical Investigation of Steer and Mowday's Model Turnover. Academy of Management Journal. 30 (4): 721-743

Robbins, Stephen. 2001. Perilaku Organisasi. (Organizatonal Behaviour) PT.Prehalindo, Jakarta.

Shore, L., \& Liden R. 1989. Percieved Organizational Support and Leader Member Exchange : Academy of Management Journal. 40 (1): 82-111

Simamora, Henry, 1997, Manajemen Sumber Daya Manusia, STIE YKPN, Yogyakarta.

Suwandi, dan Nur Indriantoro. 1999. "Pengujian Model Turnover Pasewark dan Strawser: Studi Empiris pada Lingkungan Akuntansi Publik", Jurnal Riset Akuntansi Indonesia, No.2, halaman 173-195.

Tett, R.T and Meyer J.P. 1993. Job Satisfaction, Organizational Commitment, Turnover intention and Turnover. Personnel Psychology. 46: 259-293

Vandenberg, R.J., \& Lance, C.E. 1992. Examining the Causal Order of Job Satisfaction and Organizational Commitment Journal of Management. 18: 153-167.

Yousef, D. A. 2000. “Organizational Commitment as aMediator of the relationship between islamic Work ethic and Attitudes Toward Organizational Change" Human realtion, Vol. 53 (4). 
DIDASKALIA, VOLUME 1 NUMBER 1 OCTOBER 2018

Yuyetta, Etna Nur Afri. 2002. "Pengaruh Tindakan

Supervisi dan Persepsi Kewajaran Upah serta

Promosi terhadap Keinginan Berpindah Akuntan

Publik Yunior di Indonesia", Jurnal Media

Ekonomi dan Bisnis. Halaman 92-10 